\title{
Rhizosphere Nitrification and Nitrogen Nutrition of Rice Plants as Affected by Water Management
}

\author{
W.S. Dandeniya* ${ }^{*}$ and J.E. Thies ${ }^{1}$ \\ Department of Soil Science, Faculty of Agriculture \\ University of Peradeniya \\ Sri Lanka
}

\begin{abstract}
Redox status shapes the biogeochemistry and dominant biogeochemical processes in soil environment. Nitrification is a microbiologically mediated transformation affected by the oxygen availability in soil. Nitrification rate often determines the agronomic $N$ use efficiency (NUE) since it affect the pool size of plant available $\mathrm{N}$ forms $\left(\mathrm{NH}_{4}+\right.$ and $\mathrm{NO}_{3^{-}}$) in soil. A mesocosm experiment was conducted using three rice varieties (PI312777, IR55423 and IR80508) to test the effect of soil water status on plant characters and nitrification in the rhizosphere. Two irrigation treatments as aerobic cultivation (AC) and continuously flooded condition (CF) were imposed. Plants were grown until 50 days after germination (DAG). At harvest, leaf nitrate reductase activity, physiological nitrogen use efficiency (PNUE), air-filled pore-space of roots, and biomass accumulation were determined. Also potential nitrification rate in the rhizosphere, soil moisture, $p H$, and $\mathrm{NH}_{4}^{+}$and $\mathrm{NO}_{3}^{-}$contents at three soil depths were determined. Biomass production was nearly 50\% lower under AC than under CF. Rooting depth and rhizosphere nitrification were significantly higher under $A C$ than $C F$. Rice variety and water management affected the activity of nitrifies in the rice soils. Measured soil properties and plant traits correlated significantly $(p<0.05)$. Plant $N$ status was significantly affected by water management regime resulting in higher PNUE but lower total $N$ accumulation in rice shoots grown under $A C$ than under CF. Better understanding of these interactions is needed to help farmers to manage $N$ more effectively in relation to cultivars used and intended water management regime.
\end{abstract}

Keywords: Nitrification, rhizosphere, rice, water

\section{INTRODUCTION}

Timeline to develop better rice varieties for water-saving farming systems, such as aerobic cultivation (AC) and alternate wetting and drying, is tight because physical and economic water scarcity are already threatening rice production (Tuong and Bouman, 2003). To develop and evaluate the best-fit variety for any given environment, it is crucial to understand the system components and links between them (Messina et al., 2009). Low yields obtained frequently under AC compared to wetland paddy farming is often attributed to weed pressure, effects of soil $\mathrm{pH}$, nutrient availability and pest and disease threats (Kreye et al., 2009). A controlled environmental set up is required to study the contribution of each of these factors to rice yield reduction.

\footnotetext{
1. Crop and Soil Sciences Department, Cornell University, Ithaca, NY 14853, USA

* Author for correspondence: warshisd@gmail.com
} 
The soil biogeochemistry and dominant biogeochemical processes occurring under AC and continuously flooded systems (CF) are distinctly different, especially, with regard to inorganic nitrogen $(\mathrm{N})$ availability for crop growth (Robinson, 2009). Microorganisms that respond quickly to environmental changes mediate the transformations in the $\mathrm{N}$ cycle (Haefele et al., 2008; Sooksa-nguan et al., 2009). Nitrification, the conversion of ammonia $\left(\mathrm{NH}_{3}\right)$ to nitrite $\left(\mathrm{NO}_{2}{ }^{-}\right)$and then to nitrate $\left(\mathrm{NO}_{3}{ }^{-}\right)$, is a dominant process in the $\mathrm{N}$ cycle and often determines the agronomic $\mathrm{N}$ use efficiency (NUE) of crops grown under unsaturated soil conditions, such as in AC (Barnard et al., 2005; Gujer, 2010). Nitrifiers require oxygen to oxidize $\mathrm{NH}_{3}$, thus, nitrification is typically undetectable in anoxic environments. However, in $\mathrm{CF}$, nitrification occurs to some extent in standing water and in the top few centimetres of soil, where there is sufficient dissolved oxygen, and to a significant extent in the rice rhizosphere (Adhya et al., 1996). Air that leaks or is exuded from rice roots oxygenates the rhizosphere enabling the growth of aerobic microorganisms in the root zone. Ammonium $\left(\mathrm{NH}_{4}{ }^{+}\right)$from $\mathrm{N}$-fertilization and $\mathrm{N}$-mineralization is the substrate for nitrification and; thus, an environment where both $\mathrm{NH}_{4}{ }^{+}-\mathrm{N}$ and $\mathrm{NO}_{3}{ }^{-} \mathrm{N}$ coexist is created in saturated soil moisture regime (Adhya et al., 1996; Ghosh and Kashyap, 2003; Zhou et al., 2009). Many rice varieties perform better when the growth medium has both $\mathrm{NH}_{4}{ }^{+}-\mathrm{N}$ and $\mathrm{NO}_{3}{ }^{-} \mathrm{N}$ and this phenomenon is known as partial nitrate nutrition (PNN) (Kronzucker et al., 1999). Kronzucker et al. (1999), demonstrated that the presence of $\mathrm{NO}_{3}{ }^{-}$enhances $\mathrm{NH}_{3}$ uptake and translocation from roots to shoots in rice, improving the $\mathrm{N}$ nutrition of the rice plant. They also observed that nitrate reductase enzyme activity (NRA) positively correlate with leaf $\mathrm{NO}_{3}{ }^{-}$content. The activity and community composition of ammonia oxidizers are greatly influenced by rice variety (Ghosh and Kashyap, 2003; Zhou et al., 2009). Therefore, $\mathrm{NH}_{4}{ }^{+}-\mathrm{N}$ to $\mathrm{NO}_{3}{ }^{-}-\mathrm{N}$ ratio in the root environment might be variety specific.

Deep root development of benefit plants by improving soil water extraction and plant water status when growing plants under moderately water-stressed, unsaturated soil condition (Kato et al., 2007; Price et al., 2002). Deep rooting helps to scavenge nutrients that leach down in the soil profile resulting in improved plant nutrient status. However, there will be a trade-off between biomass allocation to the root system and aboveground biomass accumulation. The presence of physical barriers to deep root growth decrease aboveground biomass accumulation in rice grown under unsaturated soil conditions (Kato et al., 2007). Hence, in greenhouse experiments where shallow pots are used and in some field studies with limited rooting depth due to fragipans or soil compaction, it is difficult to evaluate the influence of irrigation treatment on plant performance. Microcosms can be used to overcome this constraint in greenhouse experiments. Carefully designed mesocosms will help to better evaluate the response of rice to irrigation treatment.

To find best-fit varieties for water-saving rice farming, it is important to understand the links between different components of the system. This study was undertaken to assess how nitrification is linked to the nitrogen $(\mathrm{N})$ status of rice plants grown under different water management regimes.

\section{MATERIALS AND METHODS}

A mesocosm experiment was conducted to evaluate the response of three rice varieties to two different irrigation treatments: continuously flooded (CF) and aerobic cultivation (AC). Seeds of PI312777 (bred for CF) were obtained from Dale Bumpers National Rice Research Center, AR, USA; IR55423 (Apo) (bred for AC) and IR80508-B-57-3-B (ApCr) (bred for 
AC) seeds were obtained from International Rice Research Institute, Los Baños, The Philippines.

\section{Constructing mesocosms}

Mesocosms were constructed using $10 \mathrm{~cm}$ internal diameter PVC $®$ pipes cut into $1 \mathrm{~m}$ long pieces. The cylinders were lined inside with transparent high-density polyethylene $(0.116$ $\mathrm{mm}$ ) sleeves. The growth medium consisted of a mixture (by volume) of $50 \%$ medium-sized $(0.5-0.3 \mathrm{~mm})$ commercial grade sand (Quikrete Companies, Inc.), 25\% horticultural vermiculite (Whittemore Companies, Inc.), 5\% Perlite (Whittemore) and $20 \%$ air dried and sieved ( $2 \mathrm{~mm}$ sieve) topsoil (collected from a rice paddy in the Cornell Plantations, Ithaca, NY, USA). Mesocosms were watered with Hoagland's nutrient solution and irrigation treatments were imposed one week prior to planting. A continuous standing water layer was maintained in CF treatment and medium was maintained close to field capacity in AC treatment. Hoagland's nutrient solution was applied at a rate of $500 \mathrm{ml}$ per each mesocosm twice a week.

\section{Sampling}

Twenty one days old seedlings were transplanted into the mesocosms, with one seedling per cylinder. Triplicates were used for each treatment. Plants were raised at $28^{\circ} \mathrm{C}$ day and $25^{\circ} \mathrm{C}$ night temperature and a photoperiod of $14 \mathrm{~h}$ light and $10 \mathrm{~h}$ darkness. At 50 days after germination (DAG), the second leaf from the top of well-grown tillers was sampled to measure NRA. Harvesting was undertaken from 11:15 am to 11:45 am on a bright sunny day. The soil columns were removed from the mesocosms and rooting depth was recorded. Growth medium samples from 1-4 cm depth (top), $42-46 \mathrm{~cm}$ depth (middle), $88-92 \mathrm{~cm}$ depth (bottom), and from the rhizosphere (medium adhered to roots) at 1-8 $\mathrm{cm}$ depth were collected. Root system was recovered by carefully washing off the growth medium. Shoots and roots were separated. Plant and growth medium samples were placed on ice and transferred to laboratory.

\section{Plant analysis}

Plant tissue samples were oven-dried at $60^{\circ} \mathrm{C}$ for $48 \mathrm{~h}$. Dry weights of shoots were recorded and samples were analyzed for total carbon (C) and $\mathrm{N}$ using dry combustion method (automatic carbon-nitrogen analyzer NC2100, Thermo Quest Italia S.p.A., Milan, Italy). The PNUE of plants was calculated as dry biomass accumulated $\mathrm{g}^{-1} \mathrm{~N}$. The NRA of fresh rice leaves was measured using NECi NADH:NaR Enzyme Activity Assay ${ }^{\circledR}$ kit (Nitrate Elimination Co., Inc. Lake Linden, MI, USA) according to manufacturer's protocol. Nitrate reductase enzyme activity was calculated as $\mu \mathrm{mol} \mathrm{NO}_{3}^{-}-\mathrm{N}$ reduced ${ }^{-1} \mathrm{~g}^{-1}$ fresh weight (gfw). Concentrations of $\mathrm{NH}_{4}{ }^{+}-\mathrm{N}$ and $\mathrm{NO}_{3}{ }^{-} \mathrm{N}$ in leaf extracts were analyzed as described previously (Cataldo et al., 1975; Kafkafi and Ganmore-Neumann, 1997).

Root volume was measured using water displacement method (Newman, 1973). Air-filled porosity was measured using pycnometer method (Noordwijk and Brouwer, 1988). The length of a representative sample of the root system was measured by scanning the roots and analyzing the image using WinRhizo software. After taking the length measurements, the roots were oven-dried at $60^{\circ} \mathrm{C}$ for $48 \mathrm{~h}$ and specific root length (SRL) was calculated as m g dry root. 


\section{Soil analysis}

Soil samples were used to analyze moisture content (oven dry method), $\mathrm{pH}$ (1:2.5 soil:distilled water slurry), and $\mathrm{KCl}$ extractable $\mathrm{NH}_{4}{ }^{+}$and $\mathrm{NO}_{3}{ }^{-}$(using auto-analyzer 3 / Seal analytical Inc., Mequon, WI, USA). The potential nitrification rate assay (PNR) was conducted using the shaken-slurry method as described by Hart et al. (1994).

\section{Statistical analysis}

Analysis of variance (ANOVA) was performed for data from soil and plant analyses using JMP $8.0 \circledR$ software (SAS Institute Inc., Cary, NC, USA). Means were compared by LSD mean separation technique $(p<0.05)$. Correlations between plant and soil properties were determined using the residual maximum likelihood method (REML) in the multivariate analysis tool in JMP $8.0 \circledR(p<0.05)$.

\section{RESULTS AND DISCUSSION}

Plants grown under CF produced two-fold, three-fold and four-fold more biomass than those grown under AC for ApCr, PI312777 and Apo, respectively (Fig.1a.). Biomass allocation to roots was higher under $\mathrm{AC}$, as indicated by significantly lower shoot to root ratios in plants compared to CF ( $p<0.05$; Fig. 1a). Specific root length was significantly higher in plants grown under $\mathrm{AC}$ than under $\mathrm{CF}$; whereas, air-filled porosity followed a reverse trend (Fig. $1 b$ ). Roots were recovered up to $90 \mathrm{~cm}$ depth under $\mathrm{AC}$, while root were confined to the upper $20 \mathrm{~cm}$ depth in $\mathrm{CF}$.

(a)

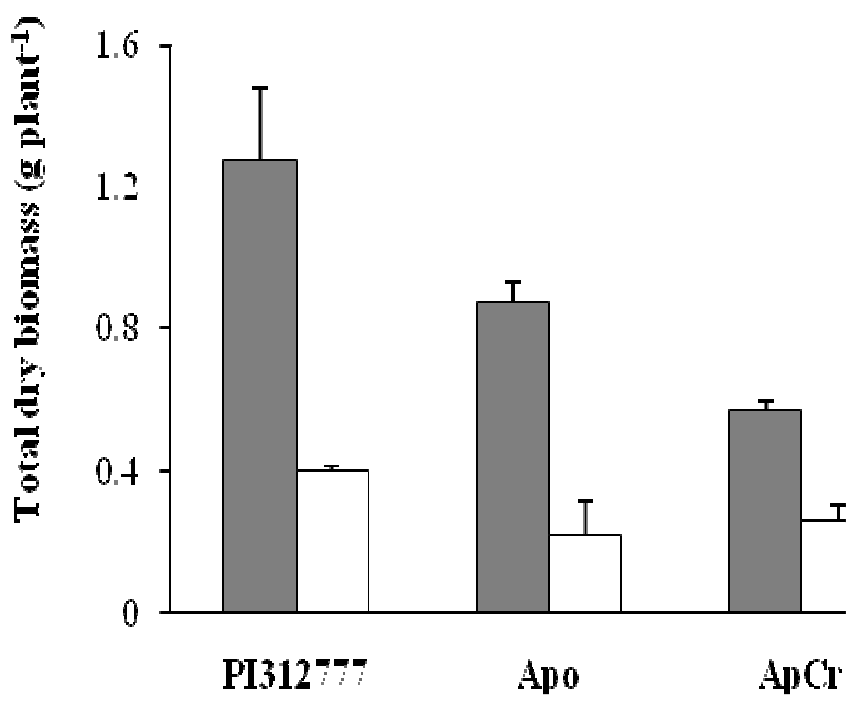


(b)

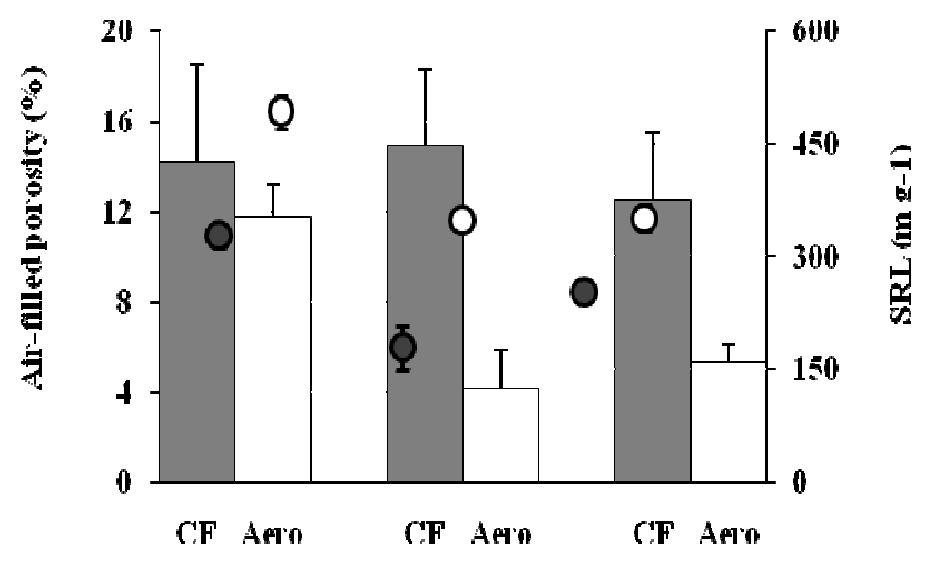

Fig. 1. Plant responses to two irrigation management regimes (grey bars $=\mathrm{CF}$; white bars $=$ AC) for three rice varieties (PI312777, Apo and ApCr) (a) Total dry biomass plant $^{-1}$ (represented by vertical bars) and mean shoot: root for each variety (represented by numbers over the bars) (b) air-filled porosity, represented by bars; and specific root length (SRL), represented by circles. Vertical error bars represent the standard deviation; $n=3$.

A common plant growth retarding factor in aerobically grown rice is root diseases. Discoloration of rice roots, an indication of root disease, was not observed in this study in plants grown under either $\mathrm{AC}$ or $\mathrm{CF}$. Measured rhizosphere soil properties correlated with plant traits (Table 1). Irrigation management had a significant effect on PNUE of the rice plants, resulting in a higher PNUE for rice grown under AC than under CF $(p<0.05)$. Leaf NRA positively correlated with PNUE and leaf $\mathrm{NO}_{3}{ }^{-}-\mathrm{N}$ content $(\mathrm{r}=0.69$ and $\mathrm{r}=0.59$, respectively) and negatively correlated with total biomass $(r=-0.62)$.

Table 1. Correlation-coefficients (r) of measured soil properties with plant traits

\begin{tabular}{|c|c|c|c|c|}
\hline \multirow{2}{*}{ Plant trait } & \multicolumn{4}{|c|}{ Soil properties } \\
\hline & $\begin{array}{c}\text { Soil moisture } \\
\text { content }\end{array}$ & $\mathrm{NO}_{3}{ }^{-} \mathrm{N}$ & $\mathrm{NH}_{4}{ }^{+}-\mathrm{N}$ & PNR \\
\hline Shoots dry weight & $0.82^{*}$ & -0.42 & 0.59 & -0.48 \\
\hline Roots dry weight & 0.89 & -0.49 & 0.64 & -0.52 \\
\hline Leaf NRA & -0.66 & 0.13 & -0.64 & 0.30 \\
\hline Leaf $\mathrm{NH}_{4}^{+}$ & 0.81 & 0.13 & -0.17 & -0.07 \\
\hline Leaf $\mathrm{NO}_{3}^{-}$ & -0.60 & 0.46 & -0.51 & 0.46 \\
\hline PNUE & -0.43 & 0.05 & -0.38 & 0.08 \\
\hline Root porosity & 0.74 & -0.14 & 0.63 & 0.22 \\
\hline SRL & -0.74 & 0.70 & -0.76 & 0.80 \\
\hline
\end{tabular}

* Bold letters indicate significant correlations $(p<0.05)$.

Nitrate and $\mathrm{NH}_{4}{ }^{+}-\mathrm{N}$ contents, and $\mathrm{pH}$ of the growth medium at different depths were affected by irrigation treatment (Fig. 2). The growth medium was more alkaline under AC treatment than under CF. At all three depths, $\mathrm{pH}$ correlated inversely with soil moisture content (at top, middle and bottom, $\mathrm{r}=-0.72, \mathrm{r}=-0.80$ and $\mathrm{r}=-0.65$, respectively, at $p<0.05$ ). Plant 
biomass negatively correlated with $\mathrm{pH}(p<0.05) . \mathrm{NH}_{4}{ }^{+} \mathrm{N}$ content in the rhizosphere negatively correlated with $\mathrm{pH}$ at top layer $(\mathrm{r}=-0.7$ at $p<0.05)$. Medium $\mathrm{pH}$ did not correlate with any other soil property or plant trait measured. Soil in the AC treatment had significantly higher $\mathrm{NO}_{3}{ }^{-}-\mathrm{N}$ and lower $\mathrm{NH}_{4}{ }^{+} \mathrm{N}$ contents than in the $\mathrm{CF}$ treatment $(p<0.05)$ at the middle and bottom of the profile.

The effects of rice variety, irrigation treatment and the interaction between variety and treatment on PNR were significant at $p<0.05$ (Fig. 3). Potential nitrification rate in the rhizosphere was significantly higher in $\mathrm{AC}$ than in $\mathrm{CF}$ and correlated positively with $\mathrm{NO}_{3}{ }^{-}-\mathrm{N}$ $(\mathrm{r}=0.85)$ and negatively with $\mathrm{NH}_{4}{ }^{+}-\mathrm{N}$ and moisture content $(\mathrm{r}=-0.59$ and $\mathrm{r}=-0.65$, respectively) in the rhizosphere growth medium. Reduced PNR resulting from growing plants under CF was significant only for PI312777 and Apo; in which, PNR was reduced nearly four-fold and three-fold, respectively (Fig. 3). Considering the number and nature of correlations that soil properties and plant traits had with moisture content in the growth medium, water management regime appears to be the underlying factor that determines the $\mathrm{N}$ nutrition of the rice plants.

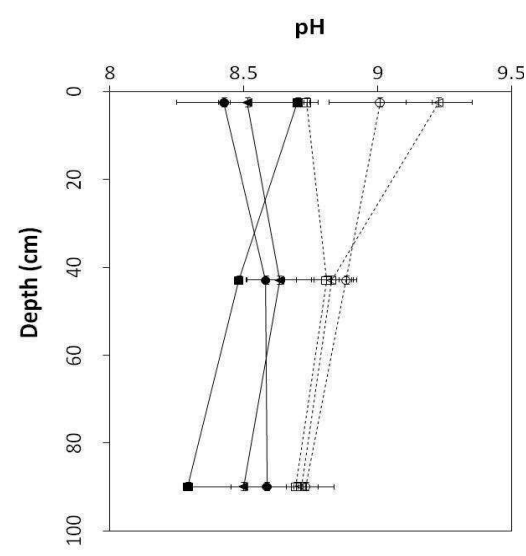

Nitrate- $\mathrm{N}$ content ( $\mu \mathrm{g} \mathrm{g}^{-1} \mathrm{dry}$ soil)

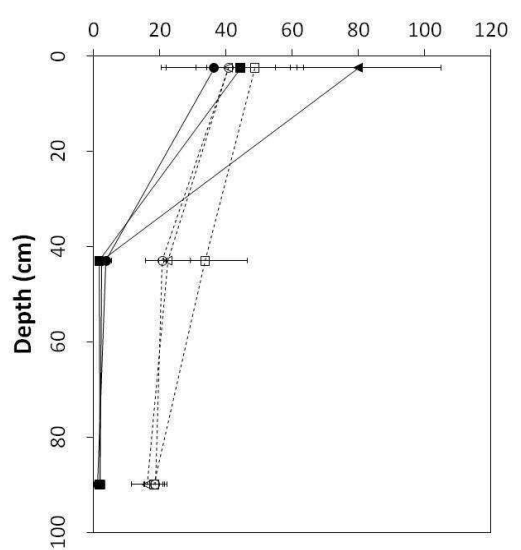

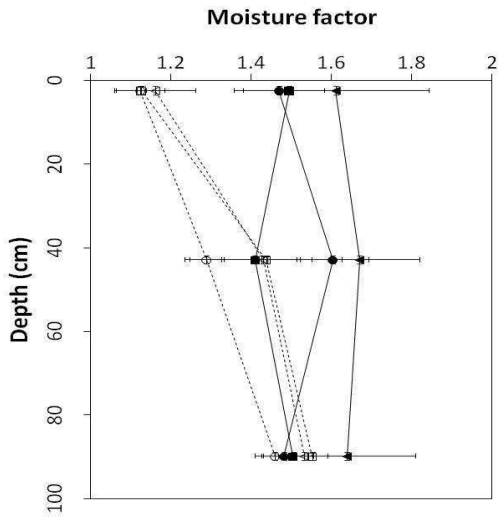

Ammonium-N content ( $\mu \mathrm{g} \mathrm{g}^{-1}$ dry soil)

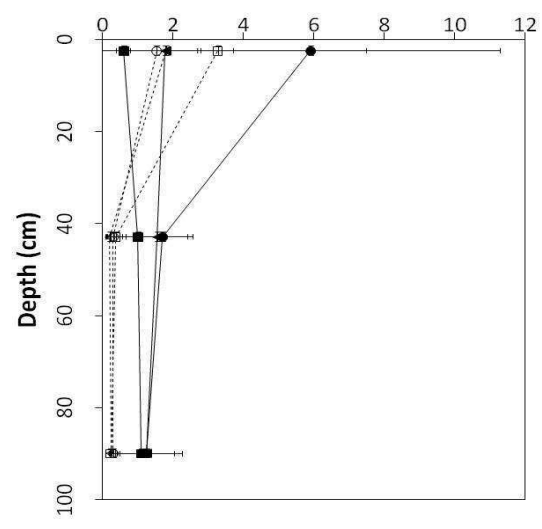

Fig. 2. Change in soil moisture content, $\mathrm{pH}, \mathrm{NO}_{3}^{-}-\mathrm{N}$ and $\mathrm{NH}_{4}{ }^{+}-\mathrm{N}$ with depth in the mesocosms. Solid lines joining solid symbols represent the $\mathrm{CF}$ treatment and broken lines joining open symbols represent the $\mathrm{AC}$ treatment. Error bars represent the standard deviation. Symbols represent $\square-$ ApCr, $\bullet-A p o, \Delta-$ PI312777; $\mathbf{n}=\mathbf{3}$. 


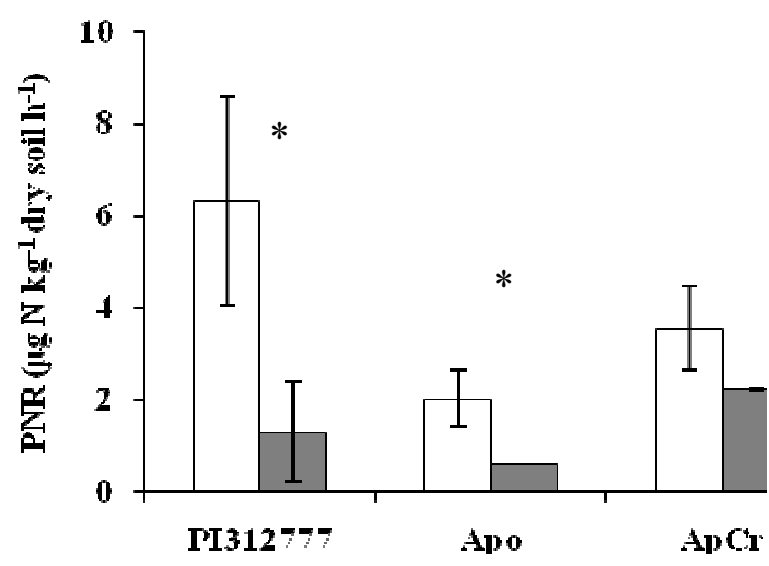

Fig. 3. Potential nitrification rates in the rhizosphere of three rice varieties (PI312777, Apo and ApCr) grown under two irrigation treatments, AC (white bars) and CF (grey bars). Vertical error bars represent the standard deviation; $\mathbf{n}=\mathbf{3}$.

* Means for PNR in the two irrigation treatments for a given variety are significantly different at $p<0.05$.

Continuous flooding of rice fields for most of the growing season is a practice that helps control weeds and parasitic nematodes (Hill et al., 2001). When grow rice under saturated soil conditions the air exude or leak through roots oxidize the rhizosphere enabling aerobic microorganisms like nitrifiers to colonize the rhizosphere (Adhya et al., 1996). Rice varieties bred for saturated soil moisture conditions have aerenchyma tissues and therefore, has a porous nature (Das and Uchimiya, 2002). As seen in the present study, the effect of moisture content of the medium on air-filled porosity varies among rice varieties (Fig. 1). This has implications on selecting parent-lines for breeding rice for water scares environments. Even though ApCr and Apo were bred for unsaturated soil conditions and should have performed better under AC (Nie et al., 2009), results from this study suggest otherwise. Between these two varieties, $\mathrm{ApCr}$ was better adapted to reduced water supply than Apo, since $\mathrm{ApCr}$ biomass yield was less affected by AC than either Apo or PI312777. The performance of Apo under $\mathrm{AC}$ and $\mathrm{CF}$ was consistent with a previous study that used this same variety (Belder et al., 2005). Since the rice plants were grown only until 50 DAG conclusive remarks cannot be made about the suitability of these varieties to water-saving farming. However, these results confirm the necessity of more careful consideration of the genotype $\mathrm{x}$ environment interaction effects on biomass accumulation in rice breeding.

Increased resource allocation to the root system when rice is grown under low moisture conditions has been reported previously (Price et al., 2002; Kato et al., 2007). As all three varieties used in this study developed a deeper root system under $\mathrm{AC}$ than under $\mathrm{CF}$ and thus, carbon allocation for roots was higher under $\mathrm{AC}$ than $\mathrm{CF}$. However, $\mathrm{N}$ concentration in plant tissues was lower under AC than CF. Although a deep root system facilitate nutrient scavenging in an environment prone to leaching losses, if allocation of more resources to the root system would compromise the nutrient concentration in the biomass, it might be disadvantageous to the plant to survive in a stressful environment (Dunbabin et al., 2003; Kato et al., 2007). Aerobically grown rice encounters stress conditions related to scavenging 
for nutrients and water, competing with weeds, withstanding disease pressure, tolerating unfavourable soil $\mathrm{pH}$ and salinity levels all of which are obscured under saturated soil conditions and only become a problem when the soil is drained (Hill et al., 2001; Belder et al., 2005; Kreye et al., 2009).

Reduced water availability in the $\mathrm{AC}$ treatment resulted in a $\mathrm{pH}$ in the growth medium that fell into a higher alkaline $\mathrm{pH}$ range than observed in the $\mathrm{CF}$ treatment $(9.0 \pm 0.2$ under $\mathrm{AC}$ Vs $8.5 \pm 0.2$ under $\mathrm{CF}$ ). High alkalinity in the AC treatment might have induced plant stress. This may have been a primary driving factor in the experimental system and is likely an underlying link between measured plant responses and soil chemical and biological properties. Soil $\mathrm{pH}$ affect on the $\mathrm{NH}_{4}{ }^{+}: \mathrm{NO}_{3}{ }^{-}$ratio in soil, which greatly influence the functional community composition of ammonia oxidizers in soil (Jia and Conrad, 2009; Stopnisek et al., 2010). It is well known that under alkaline soil $\mathrm{pH}$ (above 8.5) $\mathrm{NH}_{3}$ volatilization is a major pathway of $\mathrm{N}$ loss from soil. In addition to $\mathrm{pH}$, quality $\left(\mathrm{NH}_{4}^{+}: \mathrm{NO}_{3}{ }^{-}\right)$ and quantity of $\mathrm{N}$ available to the plants and competition for nutrients in the rhizosphere might also have contributed to poor plant performance under AC.

Under unsaturated soil conditions, nitrification rates are typically high; given that the substrate, $\mathrm{NH}_{4}{ }^{+}-\mathrm{N}$, is more readily available (Gujer, 2010). Therefore, when growing rice bred for saturated soil conditions under $\mathrm{AC}$, the plant preference for a mixture of $\mathrm{NH}_{4}{ }^{+}-\mathrm{N}$ and $\mathrm{NO}_{3}{ }^{-} \mathrm{N}$ is not always met; except for a relatively short period after $\mathrm{NH}_{4}{ }^{+}$based $\mathrm{N}$ fertilizer is applied. Application of $\mathrm{NH}_{4}{ }^{+}-\mathrm{N}$ fertilizers, along with nitrification inhibitors, increased biomass production, water uptake and drought tolerance of aerobically grown rice ( $\mathrm{Li}$ et al., 2009). Comparatively higher $\mathrm{NO}_{3}^{-}-\mathrm{N}$ availability in the rhizosphere could be a factor contributing to higher PNUE, lower $\mathrm{N}$ accumulation and lower biomass production in rice grown under $\mathrm{AC}$ compared to $\mathrm{CF}$ for the varieties used in this study.

Differences in nitrification rates in the rhizosphere environments of the three varieties could be due to several factors: (i) competition between nitrifiers and plant roots for $\mathrm{NH}_{4}{ }^{+} \mathrm{-N}$, (ii) availability of oxygen $\left(\mathrm{O}_{2}\right)$ as determined by $\mathrm{O}_{2}$ exuded by rice roots, (iii) air-filled pore space in the soil matrix and its effects on microbial activity rates, (iv) potential growth regulatory compounds in rice root exudates and, (v) competitive, fast-growing heterotrophic microorganisms in the rhizosphere (Adhya et al., 1996; Fillery, 2007; Subbarao et al., 2007). The activity of ammonia oxidizers can be inhibited by allelochemicals in plant root exudates; and, on the other hand, their activity can be stimulated by growth-enhancing, root-derived compounds (Clark and Schmidt, 1967; Subbarao et al., 2007). A nearly four-fold reduction in PNR in the PI312777 rhizosphere was observed when growing plants under CF compared to AC. The extent to which the PI312777 could oxidize its rhizosphere might be a major cause for the observed differences. In addition, PI312777 is an allelopathic rice variety. Kong et al. (2008) reported PI312777 reduced the number of cultivable ammonia oxidizing bacteria and total phospholipid fatty acids in the rhizosphere compared to a non-allelopathic variety.

Active nitrification in the rhizosphere as under $\mathrm{AC}$ increases the vulnerability of the system to low agronomic NUE because $\mathrm{NO}_{3}{ }^{-}$is prone to leaching losses (Barnard et al., 2005; Li et al., 2009). Potential ground water contamination is also a major issue in environments where there is higher nitrifier activity (Gujer, 2010). Higher $\mathrm{NO}_{3}{ }^{-}$concentrations were observed in the middle and the bottom of the mesocosms under AC compared to $\mathrm{CF}$ in the present study confirming the risk of groundwater pollution under water-saving rice farming. 


\section{CONCLUSIONS}

Soil moisture status as controlled by irrigation regimes greatly influence the chemical and biological properties of the growth media and thereby influence the plant performance. It is important to acknowledge the varietal traits including plant - microbe interactions related to nitrogen nutrition when breed rice for low water environments.

The direction that the sum of all plant/microbial interactions drives the system depends on the properties of soil matrix in which both biological partners are embedded. It is crucial to take a holistic approach in order to evaluate whether a variety is a better fit for a given environment. Environmentally and economically sound water management practices can be achieved only by understanding the components of the system and links between them.

\section{REFERENCES}

Adhya, T.K., Patnaik, P., Rao, V.R. and Sethunathan, N. (1996). Nitrification of ammonium in different components of a flooded rice soil system. Biol. Fert. Soils 23, 321-326.

Barnard, R., Leadley, P.W. and Hungate, B.A. (2005). Global change, nitrification, and denitrification: A review. Global Biogeochem. Cy. 19, GB1007.

Belder, P., Bouman, B.A.M., Spiertz, J.H.J., Peng, S., Castañeda, A.R. and Visperas, R.M. (2005). Crop performance, nitrogen and water use in flooded and aerobic rice. Plant Soil. $273,167-182$

Cataldo, D.A., Maroon, M., Schrader, L.E. and Youngs, V.L. (1975). Rapid colorimetric determination of nitrate in plant tissue by nitration of salicylic acid. Commun. Soil Sci. Plan. $6,71-80$.

Clark, C. and Schmidt, E.L. (1967). Growth response of Nitrosomonas europaea to amino acids. J. Bacteriol. 93, 1302-1308.

Das, A. and Uchimiya, H. (2002). Oxygen stress and adaptation of a semi-aquatic plant: Rice (Oryza sativa). J. Plant Res. 115, 315-320.

Dunbabin, V., Diggle, A. and Rengel, Z. (2003). Is there an optimal root architecture for nitrate capture in leaching environments? Plant Cell Environ. 26, 835-844.

Fillery, I.R.P. (2007). Plant-based manipulation of nitrification in soil: A new approach to managing N loss? Plant Soil. 294, 1-4.

Ghosh, P. and Kashyap, A.K. (2003). Effect of rice cultivars on rate of N-mineralization, nitrification and nitrifier population size in an irrigated rice ecosystem. Appl. Soil Ecol. 24, $27-41$.

Gujer, W. (2010). Nitrification and me - A subjective review. Water Res. 44, 1-19.

Haefele, S.M., Jabbar, S.M.A., Siopongco, J., Tirol-Padre, A., Amarante, S.T., Sta Cruz, P.C. and Cosico, W.C. (2008). Nitrogen use efficiency in selected rice (Oryza sativa L.) genotypes under different water regimes and nitrogen levels. Field Crop Res. 107, 137-146. 
Hart, S.C., Stark, J.M., Davidson, E.A. and Firestone, M.K. (1994). Nitrogen mineralization, immobilization and nitrification. pp. 985-1018.In: Weaver, R.W., Angle, J.S., and Bottomley, P.S. (Eds.) Methods of Soil Analysis, Part 2. Microbiological and Biochemical Properties. Soil Science Society of America. Madison, WI, USA.

Hill, J.E., Mortimer, A.M., Namuco, O.S. and Janiya, J.D. (2001). Water and weed management in direct-seeded rice: Are we headed in the right direction? pp. 491-510. In: Peng, S. and Hardy, B. (Eds.) Rice research for food security and poverty alleviation. Proceedings of the International Rice Research Conference, Los Baños, Philippines.

Jia, Z. and Conrad, R. (2009). Bacteria rather than archaea dominate microbial ammonia oxidation in an agricultural soil. Environ. Microbiol. 11, 1658-1671.

Kafkafi, U. and Ganmore-Neumann, R. (1997). Ammonium in plant tissue: Real or artifact? J. Plant Nutr. 20, 107-118.

Kato, Y., Kamoshita, A. and Yamagishi, J. (2007). Evaluating the resistance of six rice cultivars to drought: Restriction of deep rooting and the use of raised beds. Plant Soil. 300, 149-161.

Kong, C. H., Wang, P., Zhao, H., Xu, X. H. and Zhu, Y. D. (2008). Impact of allelochemical exuded from allelopathic rice on soil microbial community. Soil Biol. Biochem. 40, 1862 1869.

Kreye, C., Bouman, B.A.M., Reversat, G., Fernandez, L., Vera Cruz, C., Elazegui, F., Faronilo, J.E. and Llorca, L. (2009). Biotic and abiotic causes of yield failure in tropical aerobic rice. Field Crop Res. 112, 97-106.

Kronzucker, H.J., Siddiqi, M.Y., Glass, A.D.M. and Kirk, G.J.D. (1999). Nitrate-ammonium synergism in rice. A subcellular flux analysis. Plant Physiol. 119, 1041.

Li, Y., Gao, Y., Ding, L., Shen, Q. and Guo, S. (2009). Ammonium enhances the tolerance of rice seedlings (Oryza sativa L.) to drought condition. Agr. Water Manage. 96, 1746-1750.

Messina, C., Hammer, G., Dong, Z., Podlich, D., Cooper and M. (2009). Modelling crop improvement in a $\mathrm{G}^{*} \mathrm{E}^{*} \mathrm{M}$ framework via gene-trait-phenotype relationships. pp. 235-265. In: Sadras, V.O., and Calderini, D. (Eds.) Crop physiology: applications for genetic improvement and agronomy. Academic .

Newman, E.I. (1973). Permeability to water of the roots of five herbaceous species. New Phyt. 72, 547-555.

Nie, L., Peng, S., Bouman, B.A.M., Huang, J., Cui, K., Visperas, R.M. and Xiang, J. (2009). Alleviating soil sickness caused by aerobic mono cropping: Responses of aerobic rice to various nitrogen sources. Soil Sci. Plant Nutr. 55, 150-159.

Noordwijk, M. and Brouwer, G. (1988). Quantification of air-filled root porosity: A comparison of two methods. Plant Soil 111, 255-258. 
Price, A.H., Steele, K.A., Gorham, J., Bridges, J.M., Moore, B.J., Evans, J.L., Richardson, P. and Jones, R.G.W. (2002). Upland rice grown in soil-filled chambers and exposed to contrasting water-deficit regimes: I. root distribution, water use and plant water status. Field Crop Res. 76, 11-24.

Robinson, J.B.D. (2009). The critical relationship between soil moisture content in the region of wilting point and the mineralization of natural soil nitrogen. J. Agri. Sci. 49, 100-105.

Sooksa-nguan, T., Thies, J.E., Gypmantasiri, P., Boonkerd, N. and Teaumroong, N. (2009). Effect of rice cultivation systems on nitrogen cycling and nitrifying bacterial community structure. Appl. Soil Ecol. 43, 139-149.

Stopnisek, N., Gubry-Rangin, C., Hofferle, S., Nicol, G.W., Mandic-Mulec, I. and Prosser, J.I. (2010). Thaumarchaeal ammonia oxidation in an acidic forest peat soil is not influenced by ammonium amendment. Appl. Environ. Microbiol.

Subbarao, G.V., Rondon, M., Ito, O., Ishikawa, T., Rao, I.M., Nakahara, K., Lascano, C. and Berry, W.L. (2007). Biological nitrification inhibition (BNI) - Is it a widespread phenomenon? Plant Soil. 294, 5-18.

Tuong, T.P. and Bouman, B.A.M. (2003). Rice production in water-scarce environments. pp. 53-68. In: Kijne, J.W., Barker, R., Molden, D. (Eds.) Water Productivity in Agriculture: Limits and Opportunities for Improvement. CABI, Cambridge, MA.

Zhou, S., Nakashimada, Y. and Hosomi, M. (2009). Nitrogen transformations in vertical flow systems with and without rice (Oryza sativa) studied with a high-resolution soil-water profiler. Ecol. Eng. 35, 213-220. 